\title{
In Memoriam, Arlette Darfeuille-Michaud, PhD
}

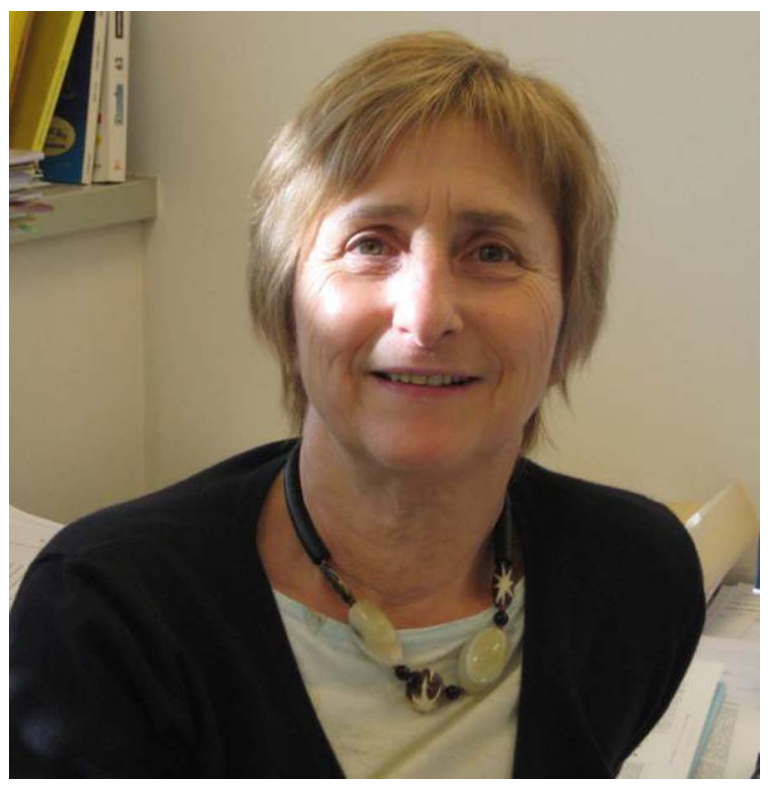

ARLETTE DARFEUILLE-MICHAUD: RESEARCHER, LECTURER, LEADER, MENTOR, AND FRIEND

It is with profound sadness that we note the loss, at age 59, of our dear friend and mentor Dr Arlette Darfeuille-Michaud on June 28, 2014, following a 15-month battle against cancer. Arlette was a Professor at Auvergne University, and director of an INSERM unit that investigates microbial-host interactions in intestinal inflammation, located in Clermont-Ferrand, France. Arlette advanced our understanding of intestinal diseases, and humanity in general, via pioneering research in gut microbiology, visionary leadership, energetic teaching, and exceptionally supportive mentorship.

Arlette lived her early years in the tiny French village of Beyssenac (in the beautiful Corrèze region) where her family owned and operated a fruit orchard. Arlette earned her $\mathrm{PhD}$ in 1987 at Auvergne University in the lab of Dr Bernard Joly, studying Klebsiella pneumoniae strains involved in nosocomial infections and Escherichia coli pathogenesis. Arlette then joined the faculty at Auvergne University as a lecturer in 1989, and then was promoted to professor in microbiology and molecular biology in 1994. Arlette then initiated a line of experimentation that would ultimately help contribute to our understanding of the pathogenesis of inflammatory bowel disease (IBD). Briefly, working with gastroenterologist Dr Jean-Frédéric Colombel and Dr Christel Neut, Arlette made the discovery, reported in Gastroenterology in 1998, that many ileal samples of Crohn's patients were colonized by a previously unappreciated class of E. coli strains. As Dr Colombel recently recalled.

"Arlette called us, very excited and enthusiastic, exclaiming that she had discovered that these Escherichia coli belonged to a new pathovar she named AIEC (for adherent-invasive E. coli). We developed, then, an intense collaboration that extended beyond science to very close friendship".

Arlette then pursued her research on characterizing diseasepromoting determinants of AIEC, which included its type 1 pili, flagella, outer membrane vesicles, and long polar fimbriae. Arlette subsequently focused on identifying host molecules that permitted AIEC colonization, resulting in her discovery in 2007 that Crohn's patients exhibit elevated expression of glycoprotein CEACAM6 that mediate AIEC adhesion. A few years later, in collaboration with Dr Paul Hofman, Arlette reported in Gut an abnormal expression of the Gp96 ER stress response chaperone on the apical side of ileal intestinal cells in Crohn's patients, favoring AIEC invasion. In 2010, Arlette reported the complete genome of a Crohn's disease-associated E. coli strain, specifically AIEC strain LF82, which is now studied as a reference strain in labs around the world. Arlette demonstrated that AIEC survive and replicate in mature phagolysosomes in macrophages, possibly as a result of defective autophagy that is thought to play a role in Crohn's disease. More recently, Arlette, with Dr Richard Bonnet and Dr Denis Pezet, revealed potential mechanisms by which tumor-associated E. coli could lead to cancer progression. These studies highlighted Arlette's extensive body of research, which included over 100 peer-reviewed manuscripts, many in the highest-ranked journals including Gastroenterology, Gut, and Journal of Clinical Investigation, and has been instrumental in leading to the emerging paradigm that inability to manage opportunistic bacteria is a pivotal event in numerous intestinal diseases, particularly IBD and cancer. The importance of Arlette's research was also recognized by numerous invited lectures and awards including the Charles Debray Research Award in Gastroenterology (1994), Jacques Piraud Research Award (2011), and Chevalier de La Légion d'Honneur (2012). Arlette firmly believed in the importance of translating discoveries in basic research to prevent and treat IBD and, consequently, attained 3 patents on her work aimed at development of IBD therapeutics.

A key ingredient in Arlette's success, in many areas of her life, was her boundless energy and her unbridled optimism. She used these qualities to inspire collaborators, students and administrators to build an INSERM research unit in Clermont-Ferrand, which Arlette often referred to as "the middle of nowhere". Founded in 2012, with Arlette as Director, and named "Microbe, Intestine, Inflammation and Host Susceptibility", the unit includes 21 full-time research personnel, 4 postdoctoral fellows and $7 \mathrm{PhD}$ students. Arlette's irrepressible enthusiasm attracted a talented cadre of basic scientists and clinicians while her visionary leadership forged a multidisciplinary approach involving an array of scientific fields including microbiology, cellular and molecular biology, immunology, gastroenterology, surgery, and internal medicine. Arlette was especially passionate about developing scientific talent. She was a spirited lecturer who taught over 3000 students in 30 years of teaching. She inspired many of her students to pursue careers in research and medicine. She was an extraordinary mentor to the numerous $\mathrm{PhD}$ students and postdoctoral fellows whom were fortunate enough to join her lab. She provided mentorship at all levels, helping her mentees in training and in career development. She made it her utmost responsibility to ensure that her students were always well prepared for presentations, especially their thesis defense. Arlette's students' thesis defenses were especially important days to her, on which she viewed herself as a proud mother taking great pride in her student's achievement, but yet being a bit melancholic to see her fledglings leave the nest. But Arlette's mentorship did not end at graduation. She continued to provide support and encouragement to her trainees up until the end of her life. Many of Arlette's trainees are now emerging 
scholars around the world (including several in ClermontFerrand) in areas related to IBD and/or on bacterial colonization and pathogenesis, and will undoubtedly continue to benefit from what they've learned from Arlette throughout their careers.

Despite her demanding career, Arlette was a wonderful wife to Jean-Eric with whom they lovingly raised 2 sons, Pierre-Yohan, who earned a $\mathrm{PhD}$ in acoustics and Vincent, who will soon complete medical school. The respite for Arlette's family was an old mill house that she and Jean-Eric beautifully restored. Arlette loved to host her scientific family at her home, especially when it was time to celebrate the numerous accomplishments of her trainees and colleagues. At such gatherings, Arlette was always thrilled to personally prepare homemade specialties from her native region.

Arlette cared deeply for all her co-workers and colleagues, in good and challenging times. We remember the loving care she gave to her friend and co-worker, Dr Anne-Lise Glasser, during her long fight against cancer while never wavering in her optimism for the best possible outcome. While the news of Arlette's illness was a stunning blow to all who knew her, it seemed to only rally her inner strength and incredible energy to fight her illness to the end and lead a productive life as long as possible. She continued to engage in numerous local and international research activities, including grant and manuscript reviews, and helping colleagues design experiments, write manuscripts, and plan conferences, while always thinking about how such activities could benefit patients with Crohn's disease. Fittingly, one of Arlette's last activities was her overseeing the successful thesis defense of her final $\mathrm{PhD}$ student, which took place the day before she left us.

Arlette will be dearly and forever missed by her family, her many friends and colleagues across the world. On behalf of all the trainees and students who received Arlette's guidance during their lifetime, we, her former $\mathrm{PhD}$ students, view ourselves as incredibly fortunate and honored to have received her mentorship and we will continue, every day, to pay tribute to her legacy.

Jennifer Raisch, Adeline Sivignon, Benoit Chassaing, Pierre Lapaquette, Sylvie Miquel, Frédéric Carvalho, Nathalie Rolhion, Marie-Agnès Bringer, Nicolas Barnich, Jérôme Boudeau, Patrick Di Martino

Correspondence Benoit Chassaing, Center for Inflammation, Immunity, and Infection, Georgia State University, Atlanta Georgia 30303; bchassaing @gsu.edu

Editor's Note This article is co-published with Gastroenterology.

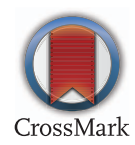

To cite Raisch J, Sivignon A, Chassaing B, et al. Gut 2014;63:1681-1682.

Gut 2014;63:1681-1682. doi:10.1136/gutjnl-2014-308182 